\title{
Kernos
}

Revue internationale et pluridisciplinaire de religion grecque antique

16 | 2003

Varia

\section{Negotiating Religion in the Cities of the Eastern}

Roman Empire

\section{Angelos Chaniotis}

\section{OpenEdition}

\section{Journals}

Electronic version

URL: http://journals.openedition.org/kernos/821

DOI: 10.4000/kernos.821

ISSN: 2034-7871

\section{Publisher}

Centre international d'étude de la religion grecque antique

\section{Printed version}

Date of publication: 1 January 2003

Number of pages: 177-190

ISSN: 0776-3824

\section{Electronic reference}

Angelos Chaniotis, « Negotiating Religion in the Cities of the Eastern Roman Empire », Kernos [Online],

16 | 2003, Online since 14 April 2011, connection on 14 November 2019. URL : http://

journals.openedition.org/kernos/821 ; DOI : 10.4000/kernos.821 


\section{Negotiating Religion in the Cities of the Eastern Roman Empire}

\section{Introduction}

Sometime in the early second century A.D., the heirs of Lucius Fabricius Longus followed the instructions given to them and erected a statue of Mercury supported by a stele containing a dice oracle in the forum of Kremna. ${ }^{1}$ Numerous dice oracles have been found in other cities of Asia Minor; ${ }^{2}$ their texts are to a great extent identical. I quote a few verses: " $1+1+1+1+3=7$ : By avoiding hostility and ill-feeling you will eventually reach the prizes"; or, " $4+4+1+1+1=11$ : [Fulfill] the whole undertaking; for it will be better. And the gods will save the sick man from his bed. Also the god proclaims that the one who is among another people will return". ${ }^{3}$ The originality of most responses is comparable to that of the fortune cookies distributed in Chinese restaurants. Vagueness and triviality have always been constitutive elements of divination. If such phrases are universally applicable as predictions, it is only because they can be associated with anyone's situation. This holds true for the Homeromanteia, i.e., Homeric verses, arranged in groups of six, which served as oracular responses; it is true for the Sortes Astrampsychi; it can be best seen in the

* Paper read at the colloquium "Religion and Society in the Eastern Parts of the Roman Empire" (Oxford, April 7, 1998). The following abbreviations are used:

I.Delphinion: A. Rehm, "Die Inschriften", in G. Kawerau, A. Rehm, Das Delphinion in Milet, Berlin, 1914.

I.Didyma: Th. WIEGAND, Didyma. Zweiter Teil: Die Inschriften von Albert Rebm, berausgegeben von Richard Harder, Berlin 1958.

I.Ephesos: Die Inscbriften von Epbesos, Bonn, 1979-1984 (Die Inscbriften griechiscber Städte in Kleinasien, 11-17).

I.Milet VI 1: Inscbriften von Milet. Teil I. A. Inscbriften n. 187-406 (Nacbdruck der Bände I 5-II 3) von Albert Rebm mit einem Beitrag von Hermann Dessau. B. Nachträge und Übersetzungen zu den Inschriften n. 1-406 von Peter Herrmann, Berlin, 1997.

I.Stratonikeia: M. ÇEтIN SAHIN, Die Inschriften von Stratonikeia, Bonn, 1981-1990 (Die Inschriften griecbischer Städte in Kleinasien, 21-22).

LSAM: F. Sokolowski, Lols sacrées de l'Asie Mineure, Paris, 1955.

LSCG: F. SOKolowski, Lois sacrées des cités grecques, Paris, 1969.

LSS: F. Sokolowski, Lois sacrées des cités grecques. Supplément, Paris, 1962.

1 G.H.R. Honsley, S. Mrtchell, The Inscriptions of Central Pisidia, including texts from Kremna, Ariassos, Keraia, Hyia, Panemoteichos, the Sanctuary of Apollo of the Perminoundets, Sia, Kocaaliler; and the Döseme Bogazi, Bonn, 2000 (IGSK, 57), p. 22-38, nº 5.

$2 C f$. the useful review of this material by J. Nollé, "Südkleinasiatische Losorakel in der römischen Kaiserzeit" $A W 183$ (1987), p. 41-49, and id., "Medien, Sprüche, Astragale. Zum Orakelwesen im kaiserzeitlichen Kleinasien", Nümberger Blätter zur Archäologie 13 (1996/97) [1998], p. $167-182$.

3 Horsley - Mitchell, o.c. (n. 1), n 5, 1. 13 and 43-45. 
alphabetical oracles, which consist of alphabetically arranged hexameters. ${ }^{4}$ Again, not unlike the Chinese fortune cookies, the verses of the alphabetical oracles contain elements of popular wisdom: occasionally, they also reflect moral values. ${ }^{5}$ They advise us that burdensome work will be rewarded; no deed escapes the Sun; we ought to fulfill the vows we make; to trust the gods; to avoid bad friends, troubles, and vain pursuits; they remind us that besides the ritual purity of the body, one should be concerned with the purity of the thoughts as well. ${ }^{6}$ One of the main messages given by the dice oracles is that a person should show courage and take his fortune in his own hands.

Longus of Kremna is the only dedicant of a dice oracle, for whom we have more information than just the name. S. Mitchell and G.H.R. Horsley have suggested that Longus is the wealthy citizen who supervised and probably sponsored the construction of the forum; he dedicated a basilica to Hadrian, the divinised Caesar Trajan, the imperial household, and the city. He served as priest of Fortuna/Tyche and as duovir. ${ }^{8}$ We are dealing with a member of the civic elite with a typical role in his community. He served in public offices; he excelled in benefactions; he was involved in religious activities, both in the emperor cult and in the cult of the Fortuna; and he made a dedication to a patron of divination. Why? Dedications of dice and alphabetical oracles were sometimes made at a god's request, possibly following an oracle or a dream. ${ }^{9}$ Longus' dedication may well have been an expression of piety. On the other hand, the place of the dedication was not a sanctuary, but the forum of Kremna, where the dice oracles could be used and the moral advice they contained

4 For the sortes Astrampsychi, see most recently W. Brashear, "New Greek Magical and Divinatory Texts in Berlin", in M. M вуеR, P. Mrrecki (eds.), Ancient Magic and Ritual Power; Leiden/New York/Cologne 1995, p. 221-231, $\mathrm{n}^{\text {os }}$ 5-6 (with bibliography). A recent publication of a Homeromanteion: F. MaLtomini, "P.Lond. 121 (= PGM VII), 1-221: Homeromanteion", ZPE 106 (1995), p. 107-122. On alphabetical oracles see, e.g., C. Brixhe, R. Hodot, L'Asie Mineure du Nord au Sud. Inscriptions inédites, Nancy, 1988, p. 133-164 (SEG XXXVIII, 1328 and 1338); Th. CorSTEN, "Ein neues Buchstabenorakel aus Kibyra", EA 28 (1997), p. 41-49; G. PETzL, "Nochmals zum neuen Buchstabenorakel", EA 29 (1997), p. 127-128.

5 See, e.g., some verses in the alphabetical oracle of Kibyra (Consten, 1.c. [n. 4]., with further

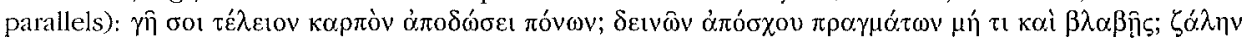

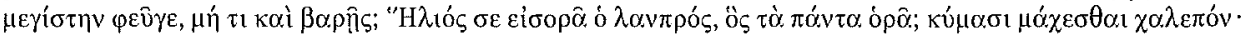

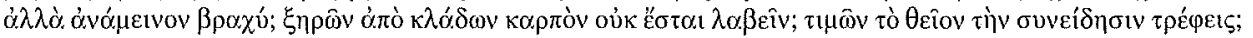

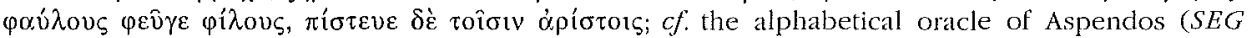

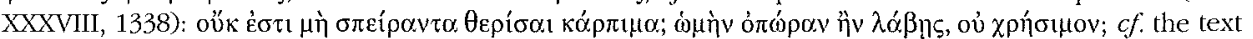

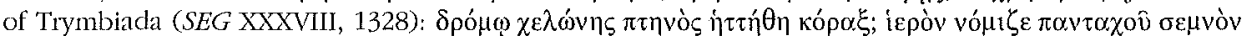

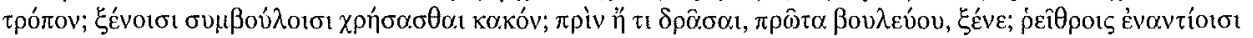

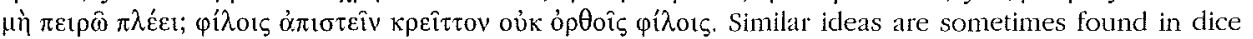

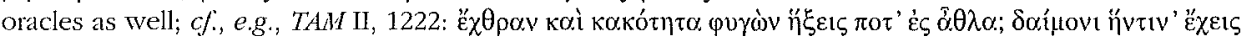

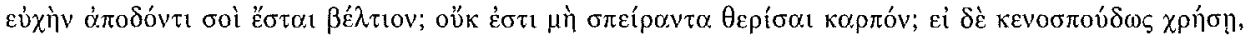

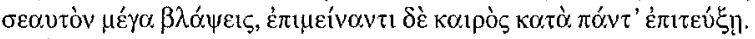

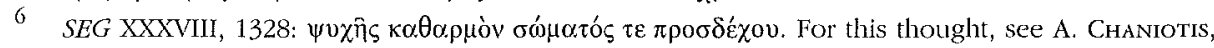
"Reinheit des Körpers - Reinheit des Sinnes in den griechischen Kultgesetzen", in J. AssmaNN, Th. Sundermeier (eds.), Schuld, Gewissen und Person, Gütersloh, 1997, p. 152-173.

7 Nollé, l.c. (n. 2), p. 47.

8 Horsley - Mícheld, o.c. (n. 1), p. 13-21, no 4, cf. p. 39, $n^{\circ} 6$

9 E.g., TAM II, 1222 (dedication of Manes); T. RITT, Hierapolis I. Fonti letteranie ed epigrafiche, Rome, 1985 , p. 53f. (with further bibliography); the dedicatory inscription of the alphabetical oracle of Kibyra is very fragmentary (COrsten, l.c. [n. 41). 
could be read by Longus' fellow citizens. ${ }^{10}$ We have no reason to assume that Longus was particularly interested in religious matters or even concerned with the moral education of his countrymen, but we also have no reason to exclude this possibility.

I have chosen Longus' dedication at the beginning of this article, because it presents a case in which the questions we can ask outnumber the answers we can even tentatively give. Longus' case points to the problems we face in the study of the religious role of civic elites. Our evidence sometimes allows us to see what their members did, not why they did it. We see them as priests; founders of agonistic festivals; sponsors of building activities and dedications; defenders of the privileges of their cities; members of private cult associations. They are praised for their patriotism, for the affection towards their fellow citizens, for their generosity and their piety. And yet, persons like Longus of Kremna, have hardly left any written record of their concerns and their motives. We know their names, not their personality. We have information about their deeds, but it is usually impossible to determine to what extent their initiatives responded to public demands or originated in their own very individual interests and concerns. Even when - or, perhaps, especially when - their proposals are presented as being in conformity with ancestral custom, it is difficult to determine whether they present continuations of old traditions, revivals, or innovations. Finally, even when we know that their proposals were accepted by the assembly, it is hard to estimate the degree of acceptance; it is difficult to detect oppositions; we do not know whether the members of the elite articulated the views of a silent majority or presented new ideas. And, usually, we do not know if their actions had a lasting or an ephemeral success. What was, e.g., the success of the mystery cult introduced by C. Calpurnius Rufinus (of Perge in Pamphylia ?) at Panóias in North Portugal? ${ }^{11}$ It is because of these methodological problems that my paper; which started optimistically as a study of the religiosity of civic elites, ended as an almost desperate enquiry into the extremely complicated and multifaceted relationship between group and individual. Instead of presenting a general picture, defining patterns, or applying models, I will attempt to point to the problems of generalisations and the need for contextualising the evidence. I will focus on a few texts, known under the very misleading term leges sacrae. Many of these sacred regulations were actually decrees, proposed by individuals, discussed in the council and the assembly, and finally approved by vote. Discussion and approval presuppose an argumentation, negotiations, sometimes disagreements. I hope to show that occasionally the written version of a decree still preserves some of the techniques of persuasion applied by individuals, usually of a high social standing and education, in the assembly and provide some evidence for the motivation of individual members of the civic elites when negotiating religious regulations with their communties.

\section{Damas of Miletos}

My first example is a Milesian decree of the mid-first century concerning two banquets (euocbia) to which the propbetes (the priest of Apollo Didymeus) at Didyma invited the kosmoi (probably a board of sacred officials responsible for some

10 Cf. Nolsé, l.c. (n. 2), p. 45. For moral advice (in the form of proverbial phrases) in the dice oracle dedicated by Longus see e.g. 1. 54f., , 70, 78f., 110, 157, 161, 212, 218.

11 Rufinus' foundation, known from one Greek and four Latin inscriptions, has been studied most recently by G. Alföldy, "Die Mysterien von Panóias (Vila Real, Portugal)", $M D A I(M) 38$ (1997), p. 176-246. 
kind of decoration in the sanctuary) and the stephanephoros invited the molpoi, the old, respected priestly board of singers. ${ }^{12}$ This decree was brought before the assembly by the presidents of the council; it was approved by the people. Formally, the initiator of the decree appears to be 'the people' (demos). It is the demos which, demonstrating its ancestral piety (eusebeia) towards Apollo Didymeus, Apollo Delphinios, and the deified emperors who were worshipped as their synnaoi, wished to increase the honors of these gods and decided to introduce the appropriate legislation (1. 12-13). But is this decree really the expression of the collective piety of the Milesians it is made out to be?

In this case we know the individual who composed the text: Tiberius Claudius Damas, president of the prytaneis, i.e., chair of the council, holder of the most important civil magistracy. Was he acting ex officio, when he composed the proposal? Was he responding to popular demand? Was he representing the interests of a particular group? Or was he personally concerned with the banquets of the kosmoi and the molpoi? These are the kind of questions we are usually unable to answer. It is less difficult in this case, however, because we happen to know Damas quite well. His name appears on Milesian coins, possibly issued during his term of office as archiprytanis, i.e., in the same year this decree was passed. They bear representations of Apollo by the river Kanachos, and of Artemis. ${ }^{13}$ L. Robert has identified these images with the gods of Didyma: Apollo Didymeus and Artemis Pythie. We also know that Damas held the office of the propbetes, for at least two terms. We are dealing with an individual with a particular interest in the old revered sanctuary of Didyma, which had however often been destroyed and neglected. ${ }^{14}$

The actual subject of the decree is presented in fewer than six lines: The acting prophetes and the stephanephoros are obliged "to organise the banquet of the kosmoi and the molpoi according to the ancestral custom and in accordance with the laws and the decrees which have been previously issued." Surprisingly enough, this short text is followed by 24 lines, devoted to measures preventing future violations of this decree and the punishment of wrongdoers. The responsible magistrates were not allowed to make a money contribution as a substitute for this celebration. We know that this occasionally happened in cities of Asia Minor. An inscription dedicated to a deity, whose name has been erased (Apollon Tempsianos?) and to the Patris at Tempsianoi records that the priest Dionysios funded the construction of an aqueduct (c. 180-192); following the request of the city he provided the money he was supposed to spend for banquets for the construction of the aqueduct (1. 4-6: $\kappa \alpha \theta \dot{\alpha} \kappa \alpha i$

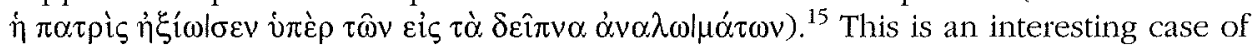
a city asking a priest not to follow the ritual traditions, in order to secure funds for the aqueduct; the text from Tempsianoi shows exactly what Damas wanted to prevent.

12 I.Delpbinion $134=$ LSAM 53; German translation and bibliography: I.Mllet VI 1, 134 (P. Herrmann). For these officials, see F. Poland, "Molpoi", RE Suppl. VI (1935), c. 511-520; A. Rehm. I.Didyma, p. 323f. (propbetes, kosmoi); R. SHERK, "The Eponymous Officials of Greek Cities, IV", ZPE 93 (1992), p. 230f. (stephanephoroi).

13 L. RoвеRт, Monnaies grecques. Types, légendes, magistrats monétaires et géographie, Genève/Paris, 1967, 47-51, pl. I.

14 Cf. REHM, I.Didyma, p. 176; RoBERT, o.C. (n. 13), p. 50.

15 H. MALAY, Researcbes in Lydia, Mysia and Aiolis, Vienna, 1999 (TAM, Ergänzungsband 23), p. $115, \mathrm{n}^{\circ} 127$. 
Any future decree which did not conform to this psepbisma should be invalid; its initiator would have to pay a fine, in addition to the divine punishment which awaits the impious; and the ritual would have to be performed, nonetheless. This psephisma is declared to be "a decree pertaining to piety towards the gods and the Augusti and to the preservation of the city" (1. 32-35). Fritz Gschnitzer has demonstrated that this and analogous formulations in Greek psepbismata give certain decrees a higher rank, a priority over others. ${ }^{16}$ Finally, two copies of the decree were to be set up in the Didymaion and the Delphion, to ensure its publicity.

Damas was obviously afraid that his decree would be as persistently ignored by future magistrates as all those earlier laws on the same matter which he quotes (1. 17-

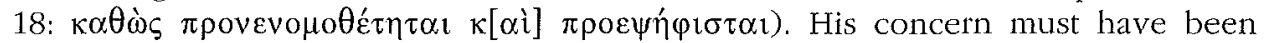
justified. Damas himself served as a propbetes, voluntarily; ${ }^{17}$ in the text which records his first term in this office Damas underscores the fact that "he performed everything which his predecessors used to perform." Such statements in honorific inscriptions indicate that some magistrates were less diligent in the fulfillment of their duties. Damas served a second term later, after a year of vacancy in this office; not a single Milesian had been willing to serve as a prophetes. This was not an unusual situation: although the sanctuary at Didyma was Miletos' pride, numerous inscriptions document a general unwillingness amongst the citizens to serve as prophetai and an even greater unwillingness to perform all the traditional rituals. The propbetes was appointed by lot among candidates representing the local Milesian districts (demoi). A long series of more than one hundred inscriptions records the names of the propbetai. The texts of the Imperial period inform us time and again that the propbetes of a particular year had been appointed "without the use of lottery" (aklerotos, aklerotei, five or six cases) ${ }^{18}$ or that he served voluntarily (autepageltos, bekousios, nine or ten cases). ${ }^{19}$ One of the prophetai, Claudius Chionis, explicitly states that he served both as arcbiprytanis and as prophetes in a year in which "no citizen was willing to accept either office." 20 Another man, Lucius Iunius Pudes, represented two demo $i^{21}$ and, as we have already seen, the position occasionally remained vacant.

Another inscription from Didyma provides us with some information about Damas' second term as a prophetes. ${ }^{22}$ It reports that Damas voluntarily served a second term as a propbetes, at the age of 81 , and that "he revived the ancestral

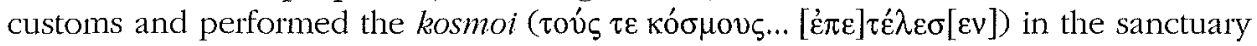
[Didyma] twelve days long" (i.e., he celebrated the banquet, $c f$. note 30). Similar references to the rites performed by the prophetes appear occasionally in the inscriptions of the prophetai. I suspect that the explicit certification that the particular priest had fulfilled his duties indicate that this was not always the case.

16 F. Gschnitzer, "Zur Nomenhierarchie im öffentlichen Recht der Griechen", in P. DimaKis (ed.), Symposion 1979. Actes du IV colloque international de droit grec et bellénistique, Ëgine 3-7 septembre 1979, Athens, 1981, p. 143-164.

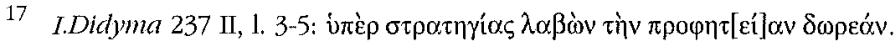

18 I.Didyma 214 B; $236 \mathrm{~B} \mathrm{III} ; 279 \mathrm{~A} ; 286,288$; restored in $\mathrm{n}^{\circ} 243$. Cf. REHM, I.Didyma p. 162 and 324.

19 I.Didyma 241, 243, 244, 252, 269, 270, 277, 278, 288; restored in $\mathrm{n}^{\circ} 289$.

20 I.Didyma 272

21 I.Didyma 215

22 I.Didyma 268. 
And some officials seem to have done more than their predecessors. An anonymous propbetes, e.g., provided the funds for a banquet for all the citizens for 13 days; he distributed money to women and virgins at a festival; he provided a dinner for the boys who officiated in a celebration; and he distributed money to the members of the council on Apollo's birthday. ${ }^{23}$ And two other propbetai claim that they had revived ancient customs - their inscriptions are, unfortunately, too fragmentary to allow us to see what exactly the object of the revival had been. ${ }^{24}$ These sporadic references to revivals seem to me to reflect failures rather than success. In any case, Damas' inscriptions leave no doubt that he went beyond what most of his predecessors were willing to do.

The inscriptions and the coins show us an individual with a vivid interest in ancestral customs. Actually, Damas is anything but a unique case in the Imperial Period. Fragments of local historians attest the interest in ancient customs and ancient myths; inscriptions make references to the respect the demos had shown towards the ancestral gods and traditional customs; both literary sources and inscriptions document a vivid interest in the past; the onomastic material confirms this impression, showing us individuals with names related to heroes and great personalities of the past; the images on the coins are full of allusions to local myths, some of which we are unable to recognise; and many inscriptions of the Imperial Period contain copies of much older documents. ${ }^{25}$ These revivals occurred at the initiative of individuals, usually educated members of the elite, as, e.g., a certain Apollonios of Aphrodisias, high priest of the civic emperor cult (and priest of Dionysos ?), author of a treatise dedicated to Orphic teletai and of a local history of Karia, full of mythological references; ${ }^{26}$ or as Hieron of Tlos, an orator of the second century whose research aimed at documenting the fraternal relationship among the Lykian cities; he reminded them of the mythological affinity and the concord between Pinara and Sidyma; he drew attention to old miracles, which he uses as etiologies for contemporary ritual customs; and he dug up old oracles which documented cultic similarities; ${ }^{27}$ or the orator P. Anteius Antiochos, who created a

23 I.Didyma 297.

24 I.Didyma 289 and 303.

25 For these phenomena see, e.g., E.L. Bowie, "The Greeks and their Past in the Second Sophistic", in M.I. Finley (ed.), Studies in Ancient Society, London, 1974, p. 166-209; P. WEIss, "Lebendiger Mythos. Gründerheroen und städtische Gründungstraditionen im griechischrömischen Osten", WIA 10 (1984), p. 179-208; A. CHANIOTIs, Historie und Historiker in den griecbiscben Inscbriften, Stuttgart, 1988; G.M. Rogers, The Sacred Identity of Ephesos, Foundation Mytbs of a Roman City, London/New York, 1991; T.S. ScheER, Mytbische Vorväter: Zur Bedeutung griecbiscber Heroenmythen im Selbstverständnis kleinasiatiscber Städte, München, 1993; R. Lindner, Mythos und Identität. Studien zur Selbstdarstellung kleinasiatischer Städte in der römischen Kaiserzeit, Stuttgart, 1994; N.M. KENNELL, The Gymnasium of Virtue: Education and Culture in Ancient Sparta, Chapel Hill, 1995, p. 87-97.

26 Apollonios served as an archiereus (FrGrHist $740 \mathrm{~T} 1=$ Suda, s.v.), and this makes a date in the Imperial Period certain. We know of a high-priest and priest of Dionysos by that name in the early third century (MAMA 454), but the popularity of this name in Aphrodisias renders an identification with the historian very speculative. Apollonios was undoubtedly the source of Stephanos of Byzantium on the older names of Aphrodisias ('City of the Lelegians' and 'Great City'); Stephanos often quotes him on Karian matters (FrGrHist F 1-10, 12-16).

27 Chaniotis, o.c. (n. 25), p. 75-85; O. CuRTy, Les parentés légendaires entre cités grecques.

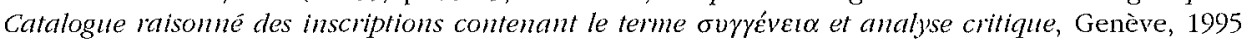


new myth concerning the adventures of Perseus in Kilikia, in order to establish the relationship between Argos and Aigeai; ${ }^{28}$ finally, the case of Symmachos of Lyttos who revived the distribution of money to tribal subdivisions (startol) in this Cretan city on the occasion of the festivals Welchania and Theodaisia and proposed a decree which obliged future epimeletai and protokosmoi to follow his example. ${ }^{29}$ The fact that inscriptions which refer to these initiatives survive does not permit the conclusion that the success of these initiatives was lasting. So, before we jump too hastily to the conclusion that the activities of local antiquarians express the collective historical conscience and the cultural memory of their respective communities, we should consider the role of personal idiosyncracies in this process.

Damas' decree offers an interesting example of a revival which was apparently accepted by the people, but whose success was ephemeral. The object of Damas' effort was a celebration attended only by a small group, the molpoi and the kosmoi; the demos was excluded not only as an active participant but persumably also as a spectator of the banquet. In the past - the decree leaves no doubt on this point - the officials responsible for the banquet had attempted to avoid an obviously burdensome duty, by making contributions in money. It seems questionable whether Damas' initiative responded to a need which had been generally acknowledged. It is also questionable whether he wanted to make sure that the molpoi and the kosmoi had yet another opportunity for feasting; he was not interested in money contributions; and his measure was certainly not aiming at increasing his popularity as the organisation of a banquet for the entire demos would have been. Taking all this into consideration, Damas' declared motive, piety (eusebeia), seems credible. It was the piety of an individual with a deep devotion to the god of Didyma, as deep as Aelius Aristides' devotion to Asklepios. Damas was interested in keeping a religious tradition alive, possibly simply for the sake of tradition, possibly out of a conservative interest in ancestral practices, possibly because of the cultic significance of the celebration he aspired to revive.

We do not know how Damas was able to win support for his proposal. Most probably he exploited his own political weight, but he also applied a strategy of persuasion which can still be recognised in the brief text of his decree and finds parallels in many other contemporary documents: (i) he referred to the importance of piety (eusebeia); (ii) he pointed to the implicit connection between his measure and the worship of the emperors; and (iii) he drew attention to the fact that this ceremony was part of the cult of a particularly important god, the leader and patron of the city (prokatbegemon). I will return to this strategy of persuasion later.

Now, what was the success of Damas' measures? From his own inscriptions we

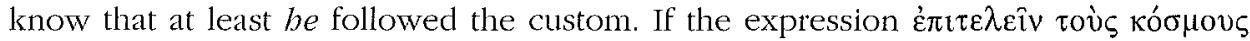
designates the banquet for the kosmoi, there are only sporadic references to this celebration among the numerous prophetai inscriptions of the Imperial Period. ${ }^{30}$.

(Hautes Études du Monde gréco-romain, 20), p. 195f., n 79; R. MerkelbaCh, "Der Glanz der Städte Lykiens", EA 32 (2000), p. 115-125.

28 ChANIOTIS, o.C. (n. 25), p. 85f., 322-324.

29 I.Cret. I, xviri, 11 ( $2 \mathrm{nd} / 3 \mathrm{rd}$ century).

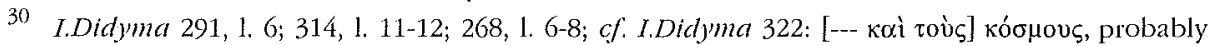

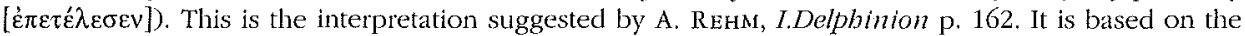

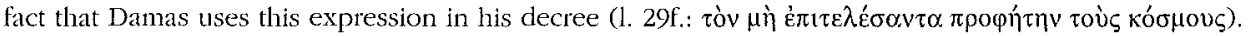

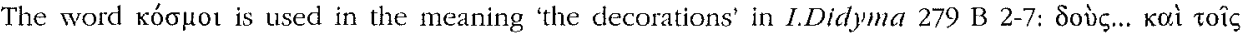

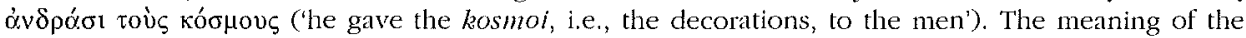


Admittedly, one should be cautious and not use this argument ex silentio to claim that the banquets of the kosmoi vanished altogether as soon as Damas died; but it would be equally wrong to assume that Damas' measure was successful only because so many efforts were made to prevent violations of the decree he had proposed. When the driving force of a revival was an individual, not the community, the revival often died with its initiator, exactly as certain festivals or cults did not survive the death of their founders. The festival of Euaresteia at Oinoanda was founded early in the reign of Severus Alexander (A.D. 222-235) by Iulius Lucius Pilius Euarestos, a teacher of literature. Euarestos, who served as agonotbetes for life, presided over the first five celebrations in the space of twenty years. He was succeeded by L. Crepereius Fronto. The sixth celebration took place, but it was the last. The agon took place within a 24 year period and then vanished, shortly after the death of its founder. ${ }^{31}$

Of course, I am not arguing that the efforts of all those men whom the literary and epigraphic evidence present as the living memory of their communities were doomed. I am simply pointing out the necessity of studying more closely the exact circumstances and the factors which may have influenced the success or failure of such efforts. With this in mind, let us turn to the next example.

\section{Amoinos of Ephesos}

This time it is a decree of Ephesos (ca. A.D. 162-164). ${ }^{32}$ The name of its author is again known: C. Laverius Amoinos, secretary of the assembly; from other texts we know that "he served in every civic magistracy", including the office of the prytanis. ${ }^{33}$ Again, we are dealing with a member of the elite. The content of the decree is made up of only a few words (1.27-32). The assembly decided to dedicate the entire month Artemision to Artemis. The rest of the text - the narratio (1. 8-27) and an hortatory formula (1. 32-34) - summarise the arguments used by Amoinos:

Artemis, the patron goddess of our city (he proestosa tes poleos) ${ }^{34}$ is honoured not only in her native city, a city which she has made more glorious than any other city with her divinity, but also among the Greeks and the barbarians, to the effect that in many places sanctuaries and sacred precincts have been dedicated to her, and temples, altars, and statues have been established, on account of the clear manifestations of her power. And the greatest proof of the respect rendered to her is the fact that she has her eponymous month, which we call Artemision, while the Macedonians and the other Greek ethne and their cities call it Artemisios. In this month festivals (panegyreis) and celebrations of a sacred month (bieromeniai) take

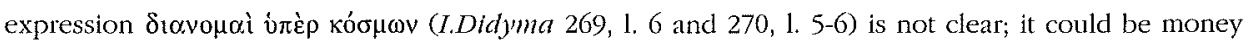
distribution for 'decorations' or money distribution for the kosmol (a substitute for the banquet ?).

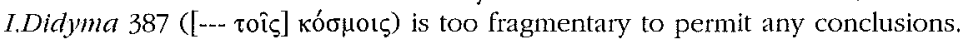

31 For the history of this agonistic festival, see A. Hall, N. Milner, "Education and Athletics. Documents Illustrating the Festivals of Oenoanda", in D. French (ed.), Studies in the History and Topograpby of Lycia and Pisidia in Memoriam A.S. Hall, London, 1994 (British Institute of Archaeology at Ankara, Monograph 19), p. 8-30.

32 I.Ephesos $24=$ LSAM 31. For discussion see also G.H.R. HorsleY, "The Inscriptions of Ephesos and the New Testament", Novum Testamentum 34 (1992), p. 154f. (with an English translation of the text).

33 I.Ephesos $1055 \mathrm{~A}$ and 1557.

$34 \mathrm{Cf}$., here, the similarity to Damas' reference to Apollo as prokathegemon. 
place, particularly in our city, which has nourished the Ephesian goddess. Because of all that, the demos regarded appropriate that the entire month, which bears this divine name, is sacred and dedicated to the goddess and has approved with this decree to establish the worship required for this month ... Thus, when the goddess is honored in an even better fashion, our city will remain more glorious and prosperous for ever.

The similarities between the decrees of Damas and Amoinos are striking. The proposals were made by members of the elite who were actively participating in the political leadership of their communities; they concern the cult of gods with a privileged relationship to the polis - the prokathegemon of Miletos and the proestosa of Ephesos; ${ }^{35}$ the subject of the decrees is worship; both decrees pertain to the welfare of the city (diamone, eudaimonestera diamone). The similarities stop here, and indeed the differences appear far more significant. Damas would have certainly had enormous difficulties explaining in practical terms how on earth the banquet of the kosmoi and the molpoi contributed to the Milesian welfare. Amoinos did not. The contribution of Artemis Ephesia to the glory, the privileges, the finances, and the security of Ephesos was obvious to all Ephesians. Amoinos was not in the defensive, trying to revive ancestral tradition (patria ethe); he was on the offensive, attempting to augment a cult which was an integral part of Ephesian self-representation. Amoinos referred, at least indirectly, to the past: to past manifestations of Artemis' power, to past contributions of her cult to the glory of Ephesos. But the past Amoinos was alluding to was not the widely unknown past which the antiquarians had to illuminate; it was the cultural memory of the Ephesians. ${ }^{36}$ Finally, Amoinos could count on the support of the entire community in his effort to augment the celebration of Artemis. The relation between the individual and the group is clearly different from the one we observed in Damas' case.

This is not the only instance in which the success of a pious enterprise depended on the material advantages it would bring. A very instructive text, an honorific decree of Gytheion for Philemon and his son Theoxenos, reports that these two citizens were willing to restore a sanctuary of Apollo (1st century B.C.). ${ }^{37}$ The sanctuary of one of the most important members of the Lakonian pantheon was located in the center of the city, near the agora (1. 6); it had been in a ruined state for many years (1. 6-7), but the city of Gytheion had obviously been unable to undertake the necessary restoration works. In the decree, the citizens of Gytheion acknowledged that father and son had bestowed upon the god the honour he deserved ( $\tau \dot{\alpha}$ ipò $\tau$ ov̀ $\varsigma$ $\theta$ coù $\varsigma$

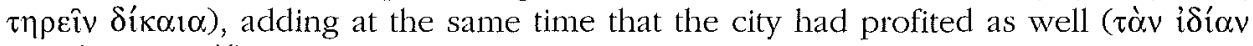
$\left.\pi \alpha \tau \operatorname{i}^{\prime} \delta \alpha \sigma v v \alpha u \xi_{\varepsilon i v}\right)$. Father and son were offered the priesthood for life, with all the

35 From the Hellenistic period onwards we have an increasing number of divine patrons of civic communities which are designated with similar epithets, e.g., Apollo Archegetes in Kos, Artemis Archegetis in Ephesos, Athena Archegetis in Athens, Dionysos Archegetis and Prokathegetes in Teos, Eleuthera Archegetis in Myra and Kyanai, Gortys Archegetes in Gortyn, Hera Archegetis in Samos, Aphrodite Kathegetis, Kathegemon, Prokathemene, and Proestosa tes poleos in Aphrodisias, Dionysos Kathegemon and Prokathegemon in Pergamon, Asklepios Prokathegemon in Kos, Athena Prokathezomene Theos in Side, Hera and Zeus Patrioi kai Proestotes tes Poleos in Amastris, etc.

36 On the asylia of the sanctuary of Artemis, see K.J. Rigsby, Asylia. Territorial Inviolability in

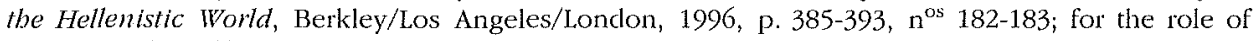
Artemis in the self-representation of Ephesos, see Rogers, o.c. (n. 25).

37 LSCG 61. 
privileges this office entailed; this possibly implies negotiations between benefactors and recipients of the benefaction.

\section{Sosandros of Stratonikeia}

We now turn to a decree of Stratonikeia (late 2 nd cent.?), ${ }^{38}$ very similar to the one proposed by Amoinos of Ephesos - at least at first sight. We are dealing, again, with the proposal of a member of the social and political elite, Sosandros, the secretary of the council. ${ }^{39}$ Sosandros proposed that every month thirty boys should come to the bouleuterion and sing a hymn; the boys were to be selected every year by the priest

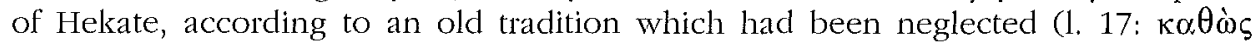

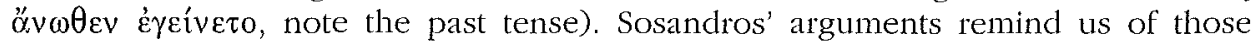
presented by Amoinos. The patron gods of Stratonikeia (1. 3: proestotes tes poleos), Zeus Panemeros (Panamaros) and Hekate, had saved the city from great and continual dangers. It was thanks to these gods that Stratonikeia had received valuable privileges (1. 2-4). ${ }^{40}$ Sosandros appeals, like Amoinos, to the well-known, visible services the gods had offered. At the same time he appeals, like Damas, to something less material: to piety. The moralizing tone of his argumentation is quite clear: "It is a good thing that we contribute to the piety towards the gods with all our zeal and that we do not neglect for a single moment to express our piety and to pray to them" (11. 4-5). Sosandros continues by recalling that the people of Stratonikeia offer sacrifices, burn incense, pray, and express their gratitude to the mighty gods ( 1 . $6)$.

For Sosandros this was not enough: "It is appropriate that we express our piety towards the gods also with the prosodos (the prayer, the request) and the threskeia (the proper conduct of worship) which is expressed through the singing of hymns" (I. 6-7). A decree of Teos of the first century A.D. ${ }^{41}$ has very similar wording, structure, and content. It refers to the benefactions (euergesiai) of the gods (1. 6), to threskeia (1. 5), to the patron of the city (prokatbegemon), i.e., the god Dionysos (1. 8-9), and to the daily singing of hymns by the youth of the city. Hymnody and the composition of new hymns were very popular in the Imperial Period. Particularly in the second century, the singing of hymns was regarded as a powerful and effective means of addressing, imploring, and appeasing the gods. Several of the metrical oracles of Klaros recommend the singing of hymns. ${ }^{42}$ One of them, found recently in Ephesos,

38 I.Stratonikeia $1101=L S A M 69$.

39 Sosandros is attested in the same function in 1.Stratonikeia 14 (late 2nd cent.?).

40 On the cults of Zeus Panamaros and Hekate, see A. LAuronier, Les cultes indigènes en Carie, Paris, 1958, p. 221-343. An attack against the city and the sanctuary by the troops of Labienus (39 B.C.) and the miraculous repulse of the attackers are reported in I.Stratonikeia 10 (with bibliography); cf. P. Roussel, "Le miracle de Zeus Panamaros", BCH 55 (1931), p. 99-103; A. Chaniotis, "Willkommene Erdbeben", in E. Olshausen, H. Sonnabend (eds.), Stuttgarter Kolloquilm zur bistorischen Geographie des Altertums 6, 1996. "Naturatastropben in der antiken Welt", Stuttgart, 1998 , p. 408-410; for the asylia of Stratonikeia, see RigsBY, o.c. (n. 36), p. 423-427, $\mathrm{n}^{\circ} 211$.

41 LSAM 28.

$42 \mathrm{~N}^{\mathrm{os}} 2$ (Pergamon), 4 (Hierapolis), and 11 (Sardes or Koloe) in the most recent collection by R. Merkelbach, J. Stauber, "Die Orakel des Apollon von Klaros", EA 27 (1996), p. 1-54. Cf. another oracle (of Apollo Didymeus ?) found at Didyma: I.Didyma $217=$ R. MERKELBACH, J. STAUBER, Steinepigramme aus dem griechischen Osten. Band 1. Die Westhïste Kleinasiens von Knidos bis Ilion, Stuttgart/Leipzig, 1998, p. $76 \mathrm{f}$. 
but concerning a city in Maionia (Koloe or Sardes) which was suffering under pestilence (c. 165 A.D.), recommends the erection of a statue of Artemis:

Her form bring in from Ephesus, brilliant with gold. Put her up in a temple, full of joy; she will provide deliverance from your affliction and will dissolve the poison (or: magic) of pestilence, which destroys men, and will melt down with her flame-bearing torches in nightly fire the kneaded works of wax, the signs of the evil art of a sorcerer. But when you have performed for the goddess my decrees, worship with hymns the shooter of arrows, the irresistible, straight shooting one, and with sacrifices, her, the renowned and vigilant virgin (transl. F. Graf). ${ }^{43}$

Groups which pursued a higher level of spirituality, in particular, practiced hymnody as a form of 'spiritual sacrifice', a tendency which culminates in Late Antiquity. ${ }^{44}$ With this in mind, as well as the religious overtones of Sosandros' decree, we may presuppose a deeper religious motivation in his efforts to revive a tradition which had been neglected in the recent past. The wording of the decree reflects this religiosity; in 15 lines, the words eusebeia (piety) and eusebein (demonstrate piety) are used five times $(1,4,7,13,18)$, and there are another two references to threskeia, the proper conduct towards the gods (1. 7 and 13).

Sosandros' decree has a quality that is different from that proposed by Amoinos; material gain is not mentioned and is not plausible; his decree did not aim at increasing the glory of the city, but the piety of the youth of the city. Sosandros himself would compose the hymn which his decree discusses; one might be tempted to see in Sosandros a fanatic composer of hymns who wanted to make sure that his works would be performed, but I am more inclined to accept the sincerity of Sosandros' declared piety. He was probably a citizen devoted to the worship of the patron gods of his community, zealous in praising the epiphany of the gods with words, and not with incense, blood, and wine, eager to educate the youth both by means of the patriotic remembrance of the past and the continual eulogy of the gods. We cannot determine how successful he was; but we do know that he was not the only member of the elite with such aspirations. Besides the interest in hymnody in the Imperial Period which has already been mentioned, there is ample evidence for the use of religious ceremonies for the acculturation of the youth. G.M. Rogers has demonstrated that this was one of the aims of the foundation of $C$. Vibius Salutaris in Ephesos (A.D. 104): the procession of statues dramatised the historical identity of Ephesos and familiarised the youth with the mythological and religious traditions of the city. ${ }^{45}$ In Athens, an inscribed oration - a text composed by Isochrysos, archon of the ephebes, gymnasiarcbos, and agonothetes - suggests that the agonistic festival of

43 SEG XLI, 981; for a detailed discussion, see F. GRAF, "An Oracle Against Pestilence from a Western Anatolian Town", ZPE 92 (1992), p. 267-279.

44 See S. Bradbury, "Julian's Pagan Revival and the Decline of Blood Sacrifice", Pboenix 49 (1995), p. 331-356. Daily religious service, employing the singing of hymns and bloodless sacrifices, is attested, e.g., in the worship of Asklepios in Epidauros (LSS 25, 2nd/3rd cent., cf. below). For further examples see A. Chaniotis, "Old Wine in a New Skin: Tradition and Innovation in the Cult Foundation of Alexander of Abonouteichos", in E. Dabrowa (ed.), Tradition and Innovation in the Ancient World, Krakow, 2002 (Electrum, 6), p. 76 sq.

45 Rogers, o.c. (n. 25), with a discussion of I.Ephesos 27. 
the Theseia gave an opportunity to the city's authorities to urge the ephebes to follow the exemplum of Theseus. ${ }^{46}$

Finally, there is a significant aesthetic component in Sosandros' initiative - and here again I detect another difference from the decrees of Damas and Amoinos. His proposal concerns itself with a hymn, i.e., with a literary text, performed with the accompaniment of music. Sosandros provides staging directions (1. 7-10): The performance was to take place every morning; thirty young boys, dressed in white, with wreaths and branches in their hands, were to come in a procession led by the paidonomos and the paidophylakes to the bouleuterion; there, they were to stand in front of the statues of Zeus and Hekate; a herald would accompany them, obviously in order to call for the cultic silence and to say the prayer; a kithara player would provide the musical accompaniment. Although the staging of religious ceremonies is well attested from the very beginning of the Greek literary tradition, it is from the Hellenistic period onwards that we may observe - particularly in the epigraphic material - an increased sensitivity towards the aesthetic and performative aspects of religious celebrations. ${ }^{47}$ An honorific decree from Kalindoia in Macedonia (A.D. 1) honors a certain Apollonios who served as the first priest of Zeus, Roma, and Augustus, provided the funds for sacrifices offered to Zeus and Augustus and for a banquet for his fellow citizens, and dedicated a statue of Augustus. ${ }^{48}$ Although Apollonios' benefactions pertained to the worship of the gods, the word eusebeia ('piety') is not used in this decree. Instead, Apollonios is praised for the luxury of the honors he had bestowed upon the gods ( $\tau \mu \mu \dot{\alpha} \varsigma, \pi 0 \lambda v \tau \varepsilon \lambda \varepsilon \hat{\imath} \varsigma$ ), the greatness of the

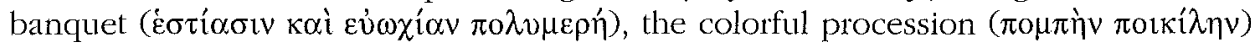

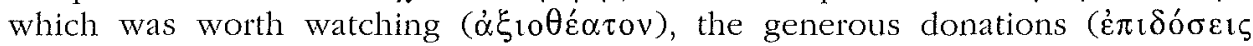
$\lambda \alpha \mu \pi \rho \sigma \tau \alpha \tau \alpha \varsigma$ ). His festival is described with the words thea ('spectacle'), apate ('impressiveness'), and diacbysis tes psyches ('entertainment'). Finally, the cult statue is called "an eternal reminiscence of Augustus' benefaction," and "an additional decoration for the city." Only at the end do we find out that this was the proper honor and an expression of gratitude to the god. A great interest in the performative dimension of rituals and in their meticulous staging is obvious even in the so terribly fragmented sacred regulation of Epidauros which deals with the daily services in Asklepios' sanctuary ( $2 \mathrm{nd} / 3 \mathrm{rd}$ cent.). ${ }^{49}$ The author of the text not only lists the rites which had to be performed, but he also gives instructions about exactly where, when, and how the rites had to be performed. We find references to the precise location of the rites ("inside, in the Metroon," "in the shrine of Aphrodite," "in front of the front-door"), to the entrance through particular doors, to the sequence of the rites and their timing ("in the first hour," "afterwards", etc.), and to the exact manner

46 IG $\mathrm{II}^{2}$, 2291; discussion: Chaniotis, o.c. (n. 25), p. 70-72. New edition of the text: S. Follet, D. Peppas Delmousou, "La légende de Thésée sous l'empereur Commode d'après le discours d'un éphèbe athénien $\left(I G \mathrm{II}^{2}, 2291 \mathrm{~A}+1125\right.$, complétés)", in Romanité et cité chrétienne. Permanences et mutations, intégration et exclusion du $I^{e r}$ au VI siècle. Mélanges en l'bonneur d'Yvette Duval, Paris, 2000, p. 11-17.

47 A. Chaniotis, "Sich selbst feiern? Die städtischen Feste des Hellenismus im Spannungsfeld zwischen Religion und Politik", in M. Wörrle, P. Zanker (eds.), Stadtbild und Bürgerbild im Hellenismuts, München, 1995, p. 147-172.

48 SEG XXXV, 744; for further bibliography see SEG XLII, 579 and XLV, 767. For a possible

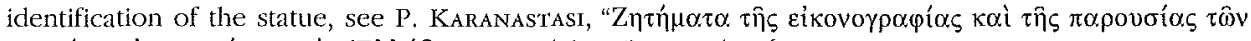

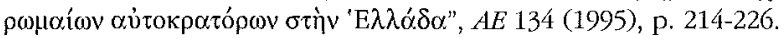

49 LSS 25. 
of performance ("the priest reclines towards the middle," "the pyrphoros is seated on a throne"). ${ }^{50}$

\section{Dryantianos of Athens}

An Athenian decree concerning the Eleusinian procession ${ }^{51}$ epitomises, in a sense, the various aspects of the religiosity of the civic elites sketched in this paper. The decree was proposed by Dryantianos, one of the Eumolpids (ca. A.D. 220). It concerns itself with the mysteries of Eleusis which were an integral part of Athenian identity and self-representation from the the fifth century B.C. onwards. ${ }^{52}$ The patriotic aspect is more than obvious. Dryantianos' declared aim was to revive the ancient customs; this is what the narratio of the decree states (1. 4-9: "because we celebrate the mysteries now, as we did in the past, and because the ancestral custom (ta patria nomima) obliges us to see to it together with the Eumolpids, that the sacred things are carried from Eleusis to Athens and from the city back to Eleusis"). Further references to the tradition follow: the supervisor of the ephebes should be ordered "according to the ancient custom" (1. 9-11: kata ta archaia nomima) to lead the young men "in the customary manner" (1. 12: meta tou eitbismenou schematos); another official, the "cleanser" (phaidyntes) should announce to the priestess of Athena the arrival of the sacred things "according to the custom of the forefathers" (1. 16: kata ta patria). The preoccupation with the maintainance of these customs implies that they were sometimes neglected. Indeed, "the kosmetes (the supervisor of the ephebes) who is in office, year after year, should take care that this custom will never be omitted and the piety towards the goddesses will not be neglected" (1. 2225).

Dryantianos is, however, not only appealing to piety and tradition. He is clearly interested in impressing an audience with a spectacular show. The ephebes should march in armour, wearing myrtle garlands (1. 25-27). His purpose is explicitly stated: "so that the sacred objects will be carried with a stronger escort and a longer procession" (1. 30-31). Finally, he places an educational aim in the foreground (1. 3133): his decree will ensure that the ephebes participate in the civic worship of the

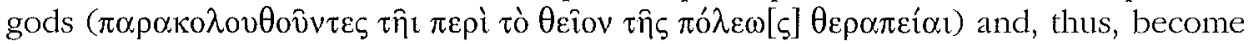

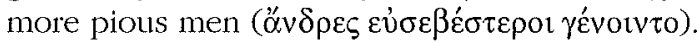

\section{Strategies of persuasion: remembrance, performance, guidance}

Dryantianos' decree allows us to recognise a strategy of persuasion in the council and in the assembly, which I sum up with the words remembrance, performance, and guidance: remembrance of the past services of the gods, performance of an aesthetically pleasing celebration; and guidance - the assumption of a leading role in the moral education of the fellow citizens, and, more importantly, in the education and the acculturation of the youth.

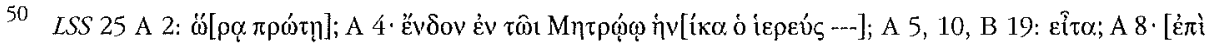

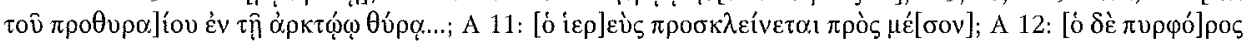

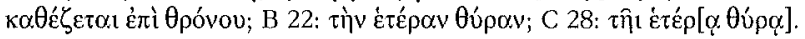

51 LSCG 8.

52 See, e.g., J. Day, The Glory of Atbens. The Popular Tradition as Reflected in the Panathenaicus of Aelius Aristides, Chicago, 1980, p. $15-38$. 
Remembrance, performance, and guidance appear as the responsibility of members of the elite; at the same time they presuppose an audience: the people who are guided, the spectators of the performance, and the participants in the cultural memory. The members of the elite had to win the support both of their peers and of 'the people in the dark', the anonymous masses of the assembly. We have the decrees which were approved, but there must have been many proposals which had failed to win the people's favor. The efforts of the members of the elite took place in an arena of competing initiatives; therefore, strategies of persuasion were necessary.

We have seen some of the techniques applied by members of the elite: They referred to the importance of the initiative for the emperor cult (Damas); they focused on gods with a privileged position in the city's pantheon and history (Damas, Amoinos); they referred to the material advantages the revival or the augmentation of a cultic event would bring (Amoinos); they were interested in the aesthetic qualities of the celebrations (Sosandros, Dryantianos); and they all considered moral, educational, and religious values. The detailed study of the case of Damas of Miletos, a unique case in which we have plenty of information about the proposer of a decree, has suggested that sometimes new impulses given to a cultic tradition stemmed from the idiosyncracy and the personality of the proposer and was not deeply rooted in the piety of the community. The preservation of a decree on stone does not necessarily mean that the decree was respected by the community for a long period of time.

The negotiation of religious matters was a multifaceted process, in which religiosity was only one of many factors. Although piety was always explicitly evoked, this may be just part - an indispensable part, though - of a social play. Whenever arguments are used, one should remember Babrius' fable of the wolf and the lamb (no. 89): When the hungry wolf sees a lamb on a meadow, he has to disguise the cause of his action - his hunger - with a series of historical and moral arguments (enklemata). He claims that he is entitled to eat the lamb because it had insulted him, because it had eaten his grass and drunk his water. When the lamb demonstrates the invalidity of the arguments, the wolf eats it nonetheless, just making a brief comment: "You will not deprive the wolf of his lunch, only because you have better arguments."

Seminar für Alte Geschichte

Angelos Chaniotis

Marstallhof 4

D - 69117 Heidelberg

e-mail: angelos.chaniotis@unz.umi-beidelberg.de 